\title{
Pelatihan Teknik Permainan Konsentrasi pada Guru Sekolah Dasar Muhammadiyah Pahandut Palangka Raya
}

\author{
Concentration Game Technique Training for Muhammadiyah Elementary School Teacher \\ Pahandut Palangka Raya
}

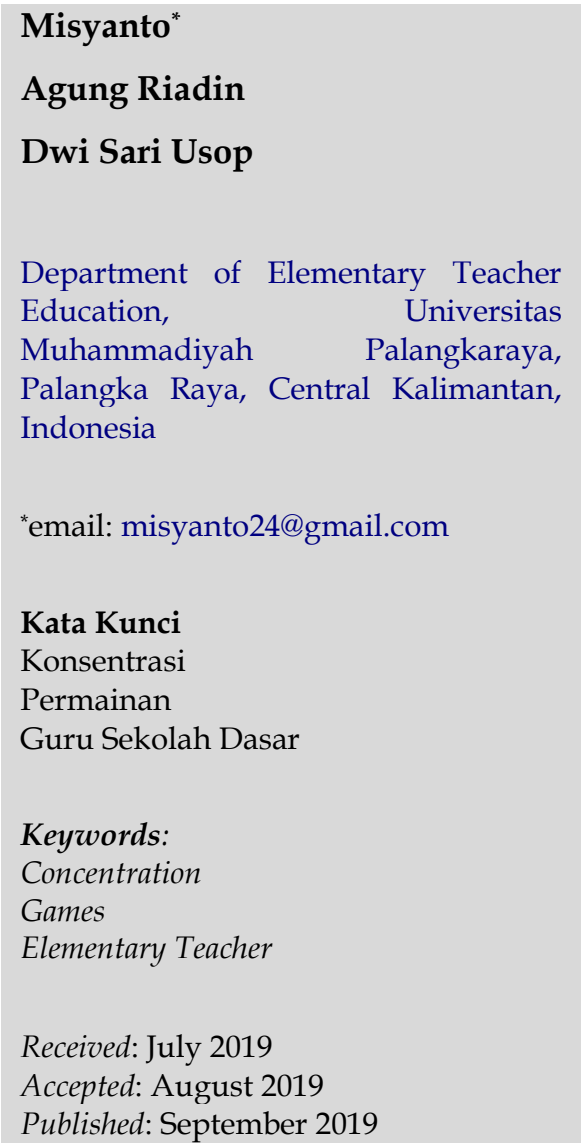

\begin{abstract}
Abstrak
Konsentrasi sebagai suatu aspek penting penguasaan materi. Khususnya, bagi peserta didik di sekolah dasar. Usia yang masih sangat muda, aktif, dan senang bermain, akan kesulitan memahami materi pelajaran saat kekurangan konsentrasi. Memahami pelajaran di sekolah mengalami kemudahan ketika dipadukan dengan permainan. Pelatihan teknik permainan konsentrasi pada guru SD Muhammadiyah Palangka Raya bertujuan mengembangkan pengetahuan dan keterampilan guru menggabungkan permainan dengan pelajaran sehingga menghasilkan pembelajaran yang bermakna.
\end{abstract}

\begin{abstract}
Concentration is an important aspect of mastering the material. Especially for students in elementary school. The age that is still very young, active, and enjoying to play, will have difficulty in understanding the subject material when they lack concentration. Understanding lessons at school experiences ease when combined with the game. The concentration game technique training for Muhammadiyah Elementary School teachers in Palangka Raya aims to develop knowledge and skills for teachers to combine games with lessons so that they can produce meaningful learning.
\end{abstract}

(C) 2019 Authors. Published by Institute for Research and Community Services Universitas Muhammadiyah Palangkaraya. This is Open Access article under the CC-BY-SA License (http://creativecommons.org/licenses/by-sa/4.0/). DOI: https://doi.org/10.33084/pengabdianmu.v4i2.912.

\section{PENDAHULUAN}

Guru menjadi pilar utama sebagai teladan bagi peserta didik di sekolah dasar yang masih dalam taraf belajar untuk dapat memiliki pribadi yang dewasa. Artinya, pribadi yang beriman dan bertaqwa kepada Tuhan yang Maha Esa sesuai dengan kompetensi yang harus dimiliki peserta didik yang tertuang di dalam tujuan pendidikan nasional (Karlina et al., 2019; Rahardjo, 2017). Melalui perannya sebagai guru sekolah dasar, seorang guru harus memberikan dasar-dasar pendidikan yang menjadi bekal bagi peserta didik atau seorang anak agar memiliki pengetahuan yang luas, kepribadian yang sehat, serta ketrampilan yang memadai untuk digunakan pada usia dewasa (Kumar \& Ahmad, 2008; Sylva, 1994). Masalah yang muncul selanjutnya adalah menciptakan pembelajaran yang kreatif dan inovatif sesuai dengan kebutuhan peserta didik. Selain itu, kurikulum 2013 mengarahkan peserta didik untuk belajar secara mandiri sehingga memerlukan energi yang cukup besar (Anwar, 2018). Keterampilan guru sangat diharapkan untuk membantu peserta didik 
menggunakan energinya dengan maksimal (Candralaela, 2018).

Peserta didik di sekolah dasar adalah peserta didik yang masih dalam taraf usia bermain. Keinginan untuk bermain tampak lebih besar daripada keinginan untuk belajar. Oleh karena itu, peserta didik di sekolah dasar dikenal aktif di dalam segala hal (Yamin, 2017; Munirah, 2015). Sebagian besar dari peserta didik di sekolah dasar tidak malu-malu saat bertanya pada guru, mengangkat tangannya saat ingin menjawab pertanyaan guru (Osher et al., 2014). Mereka juga senang mengobrol bersama teman sebangkunya atau teman-teman lainnya. Menggambar saat guru sedang menjelaskan materi atau tugas. Berjalan kesana kemari untuk sekedar ngobrol dan bermain dengan teman di dalam kelas atau berlari keluar kelas untuk menemui teman di kelas lain atau hanya untuk pergi ke toilet. Bahkan, membeli jajan. Adapula yang makan di kelas. Tidak jarang ditemukan anak-anak yang berkelahi dan menangis di kelas (Sukriyatun, 2016; Nurhizra, 2018).

Perkembangan teknologi saat ini menonjolkan kreativitas tinggi yang membawa pengaruh besar bagi anak-anak, remaja, maupun orang dewasa (Saputra et al., 2017; Setiawan, 2016). Tuntutan zaman yang serba instan dan perkembangan teknologi mengarah pada satu produk yang sangat diminati anak-anak, yakni smartphone. Sayangnya, tidak boleh membawanya ke sekolah. Berhadapan dengan smartphone, seseorang dapat berkonsentrasi berjam-jam. Namun, ketika diminta untuk belajar, hanya sebentar saja konsentrasi tersebut bertahan. Seluruh hal tersebut di atas, harus dapat dikuasai dan dikendalikan oleh guru di sekolah dasar. Guru hendaknya dapat mengatur dan membimbing agar peserta didik mau mendengarkannya dan dapat menangkap serta memahami materi yang diberikan (Abdurakhman \& Rusli, 2015; Ibrahim et al., 2014).
Masyarakat sasaran yang menjadi subyek pengabdian kepada masyarakat adalah Guru Sekolah Dasar (SD) Muhammadiyah Palangkaraya. Ada 13 guru, terdiri atas enam guru laki-laki dan tujuh guru perempuan, termasuk kepala sekolah. Setiap tahun SD Muhammadiyah Palangka Raya menerima peserta didik. Ragam fasilitas dan kompetensi dikembangkan sebagai upaya untuk menjadikan sekolah yang mereka asuh menjadi sekolah dasar yang menarik minat orang tua menyekolahkan anak-anaknya di sana. Harapannya adalah agar anak-anak mereka memperoleh pendidikan yang berkualitas. Tujuan dari kegiatan Pengabdian ini adalah untuk mengembangkan pengetahuan dan keterampilan guru menggabungkan permainan dengan pelajaran sehingga menghasilkan pembelajaran yang bermakna.

\section{METODOLOGI}

Pelatihan ini dilaksanakan pada tanggal 3 sampai dengan 6 Desember 2018. Metode yang digunakan dalam pengabdian kepada masyarakat "Pelatihan Permainan Konsentrasi Pada Guru SD Muhamamdiyah Pahandut" adalah berupa pelatihan. Pelatihan yang diberikan adalah bagaimana cara atau strategi guru dalam menggunakan teknik permainan konsentrasi yang bisa membantu guru dalam mengkondisikan kelas dalam pembelajaran.

\section{HASIL DAN PEMBAHASAN}

Kegiatan pelatihan permainan konsentrasi bagi SD Muhammadiyah Pahandut Palangka Raya melibatkan satu orang mahasiswa semester tujuh, berjenis kelamin laki-laki. Mahasiswa tersebut membantu di dalam mempersiapkan kebutuhan pada saat kegiatan pelatihan berlangsung, serta bertugas untuk mendokumentasikan kegiatan. Kegiatan pengabdian kepada masyarakat yang dilakukan merupakan kegiatan pelatihan, dilaksanakan 
pada tanggal 3 sampai dengan 6 Desember 2018. Pada tanggal 3 dan 4 Desember 2018 dilaksanakan tahap persiapan kegiatan, kemudian pada tanggal 5 dan 6 Desember 2018 tahap pelaksanaan kegiatan. Permainan konsentrasi yang diberikan berjumlah sembilan jenis permainan. Permainan-permainan tersebut adalah:

1. Berburu tiket

2. Person to person

3. Tesjari tangan

4. Berhitung maju mundur

5. Bola bertuah

6. Berkirim surat

7. Berburu binatang

8. Mengingat angka

9. Kahoot game.

Kegiatan pelatihan menggunakan bantuan media proyektor LCD, menampilkan prosedur atau aturanaturan dalam permainan konsentrasi. Kegiatan dimulai dengan pembukaan. Diawali dengan sambutan ketua tim dan ibu kepala sekolah. Kemudian dilanjutkan dengan presentasi permainan konsentrasi. Dimulai dengan permainan berburu tiket sampai permainan mengingat angka.

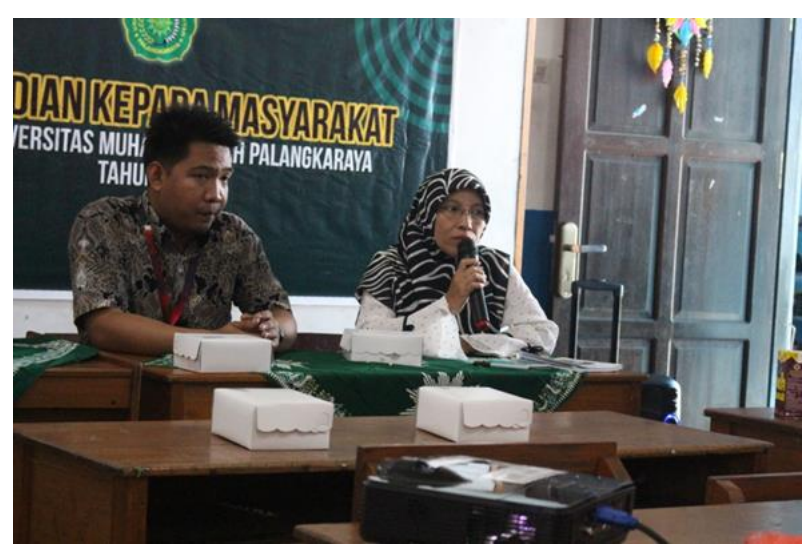

Gambar 1. Sambutan dari Kepala Sekolah SD Muhammadiyah Palangka Raya

Setiap selesai menjelaskan satu permainan, peserta (para guru) diajak untuk mempraktekkan permainan. Permainan yang dipraktekkan langsung dipimpin oleh tim pengabdian masyarakat. Sesekali tim meminta salah seorang guru untuk memimpin di dalam praktek permainan.

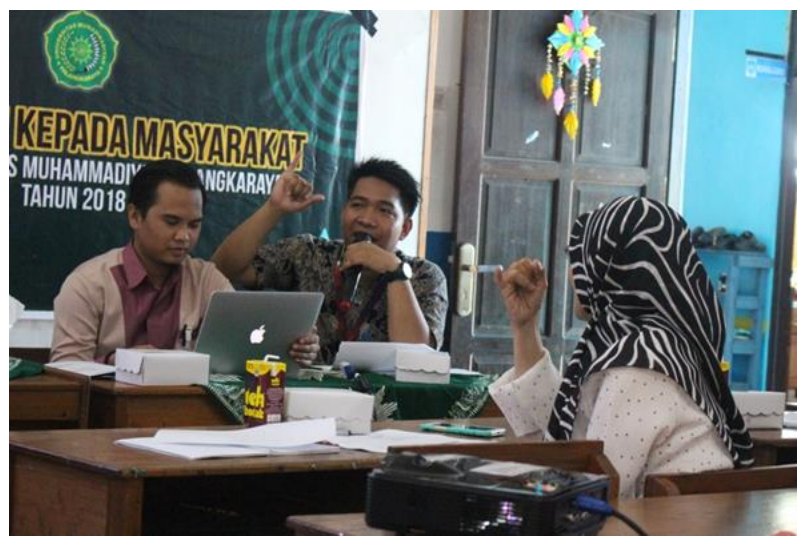

Gambar 2. Pemberian Materi

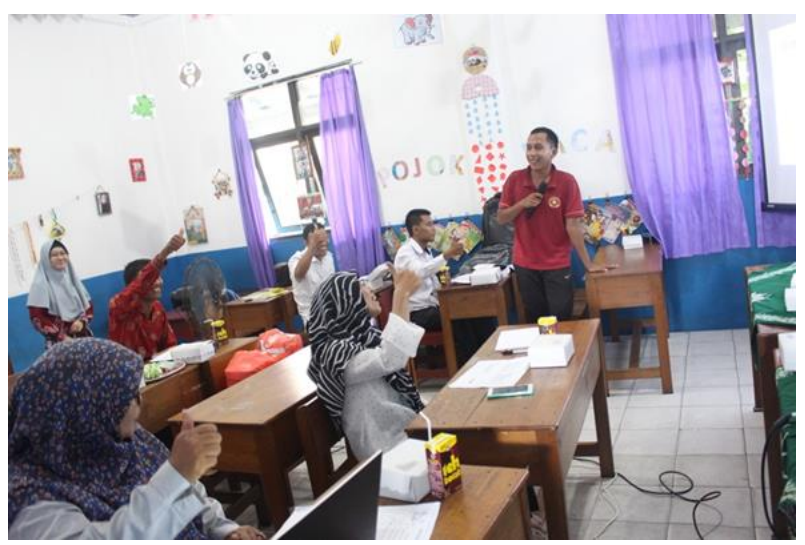

Gambar 3. Praktek Teknik Permainan Konsentrasi

Sesi tanya jawab dilakukan secara fleksibel. Peserta pelatihan diijinkan bertanya saat tim melakukan penjelasan rangkaian permainan. Setiap tim selesai menjelaskan satu permainan, peserta dapat mengajukan petanyaan. Kesempatan bertanya juga diberikan setelah seluruh rangkaian permainan selesai disampaikan. Pertanyaan-pertanyaan yang diajukan peserta pelatihan antara lain :

1. Kapan waktu yang tepat untuk memberikan permainan pada peserta didik?

2. Dapatkah permainan konsentrasi ini diaplikasikan pada setiap mata pelajaran lain? 
3. Bagaimana caranya agar dapat menjadi guru yang kreatif?

4. Terkait dengan beberapa media pembelajaran, dapatkah media pembelajaran diganti ?

Selain itu, beberapa permainan mengisyaratkan pemberian hadiah dan hukuman. Pemberian hadiah dilakukan sebagai bentuk penghargaan terhadap kinerja peserta atau peserta didik nantinya. Sedangkan pemberian hukuman dimaksudkan sebagai pembelajaran bagi peserta atau peserta didik agar dapat lebih bekerja keras di dalam setiap pekerjaan atau aktivitas agar mendapatkan hasil yang maksimal. Selain itu, pemberian hukuman juga dimaksudkan agar peserta didik nantinya lebih berkonsentrasi saat jam pelajaran berlangsung, serta memahami bahwa pada setiap hal ada konsekuensi yang harus diterima. Permainan ditutup dengan permainan Kahoot game, di mana permainan ini menggunakan fasilitas smartphone dan koneksi internet.

Kegiatan pelatihan permainan konsentrasi pada guruSD Muhammadiyah Pahandut Palangka Raya berjalan lancar. Guru-guru di SD Muhammadiyah menyatakan bahwa kegiatan pelatihan ini menambah khasanah pengetahuan mereka. Beberapa permainan sudah pernah dimainkan. Hanya saja tidak tahu namanya atau nama permainan yang berbeda. Salah seorang guru menyarankan kepada tim pengabdian masyarakat agar menggunakan video di dalam penyampaian materi. Tujuannya agar materi yang disampaikan lebih cepat diserap.

Penggunaan ruang yang lebih luas sangat membantu di dalam pelaksanaan kegiatan. Sebab, beberapa permainan membutuhkan ruang yang cukup luas dan jumlah pemain yang lebih banyak. Dengan demikian, waktu yang digunakan juga semakin banyak. Masyarakat sangat berkontribusi di dalam kegiatan pelatihan ini. Guru-guru di SD Muhammadiyah
Palangka Raya sangat aktif dan dapat bekerja sama dengan tim pengabdian masyarakat.

\section{KESIMPULAN}

Melalui pelatihan ini mitra akan memiliki pemahaman mengenai konsep anak berkebutuhan khusus, dimulai dari pengertian, penyebab, cara mengetahui, serta cara menangani anak tersebut. Selain itu, mitra juga diberikan pengetahuan mengenai sumber belajar untuk anak berkebutuhan khusus serta pengaplikasiannya. Dalam hal ini, sumber belajar yang diberikan berupa jenis-jenis permainan yang dapat digunakan di dalam proses pembelajaran secara mudah yang bermanfaat untuk meningkatkan konsentrasi anak berkebutuhan khusus di dalam belajar. Mitra diharapkan mampu menyesuaikan jenis-jenis permainan yang telah diberikan dengan kondisi di kelas saat pembelajaran sedang berlangsung. Permainan tersebut secara khusus memang diperuntukkan bagi anak berkebutuhan khusus dalam rangka meningkatkan konsentrasi. Namun, secara tidak langsung juga berfungsi untuk memberikan kepekaan bagi anak berkebutuhan khusus itu sendiri terhadap lingkungannya. Dengan demikian, kekurangan yang dimiliki dapat tertutupi

\section{UCAPAN TERIMA KASIH}

Program Pengabdian ini terlaksana atas bantuan dan dukungan pendanaan dari LPPM Universitas Muhammadiyah Palangkaraya Tahun 2018.

\section{REFERENSI}

Abdurakhman, O., Rusli, R.K. 2015. Teori Belajar dan Pembelajaran. Didaktika Tauhidi: Jurnal Pendidikan Guru Sekolah Dasar. 2(1):1-28. http://dx.doi.org/10.30997/dt.v2i1.302

Anwar, B. 2018. Kompetensi Pedagogik sebagai Agen Pembelajaran. Jurnal Shaut Al-Arabiyah. 
6(2):114-125.

https://doi.org/10.24252/saa.v6i2.7129

Candralaela, F., Jubaeddah, Y., Ningsih, M.P. 2018. Penerapan Video Pembelajaran Untuk Peningkatan Kompetensi Pekerjaan Sosial Pada Peserta Didik Di SMKN 15 Bandung. FamilyEdu: Jurnal Pendidikan Kesejahteraan Keluarga. 4(2):82-92.

Ibrahim, I., Mujahidin, E. Saefudin, D. 2014. Analisis Terhadap Komunikasi Pembelajaran di Lembaga Pendidikan Islam: Studi Kasus di MAN Kabupaten Karawang. Ta' dibuna: Jurnal Pendidikan Islam. 3(2):122-140. http://dx.doi.org/10.32832/tadibuna.v3i2.56 7

Karlina, Zein, A., Zulheddi. 2019. Kompetensi Kepribadian Guru Menurut Ibnu Sahnun (Studi Analisis Kitab Adâb Al-Mu'allimîn). Edu Riligia: Jurnal Ilmu Pendidikan Islam dan Keagamaan.3(2):164-182.

Kumar, S., Ahmad, S. 2008. Meaning, aims and process of education. In School of Open Learning. Newark: Science and Education Publishing.

Munirah, M. 2015. Sistem Pendidikan di Indonesia: Antara Keinginan dan Realita. Auladuna: Jurnal Pendidikan Dasar Islam. 2(2):233-245.

Nurhizra. 2018. Peningkatan Hasil Belajar Siswa Tentang Operasi Hitung Penjumlahan Dan Pengurangan Bilangan Bulat Dengan Menggunakan Alat Peraga Kartu Positif Dan Negatif Di Kelas VSDNTondoG. Jurnal Kreatif Online. 6(2):93-116.

Osher, D., Kenziora, K., Spier, E., Garibaldi, M.L. 2014. School Influences on Child and Youth Development. In Sloboda, Z., Petras, H. (Eds). Defining Prevention Science. Advances in Prevention Science. Boston: Springer. https://doi.org/10.1007/978-1-4899-7424-2_7

Rahardjo, S. 2017. Mendesain Profil Guru Berkarakter Cerdas. Jurnal Pendidikan Ilmu Sosial. 27(1):3040. https://doi.org/10.2317/jpis.v27i1.5118

Saputra, G.W., Rivai, M.A., Su'udah, M., Wulandari, S.L.G., Dewi, T.R., Fitroh, F. 2017. Pengaruh Teknologi Informasi Terhadap Kecerdasan (Intelektual, Spiritual, Emosional dan Sosial) Studi Kasus: Anak-Anak. Studia Informatika:
Jurnal Sistem Informasi. 10(2):77-88. https://doi.org/10.15408/sijsi.v10i2.7755

Setiawan, M.A. 2016. Peranan Teknologi Informasi dalam Bimbingan dan Konseling. Bitnet: Jurnal Pendidikan Teknologi Informasi. 1(1):46-49. https://doi.org/10.33084/bitnet.v1i1.770

Sukriyatun, G. 2016. Penerapan Metode Tanya Jawab untuk Meningkatkan Pemahaman Peserta Didik pada Mata Pelajaran IPS (Sejarah) di Kelas 9.1 tentang Perang Dunia II, DiSMPN16 Kota Bogor Tahun Pelajaran 2012/2013. Istoria: Jurnal Pendidikan dan Sejarah. 11(2):58-70. https://doi.org/10.21831/istoria.v12i1.9545

Sylva, K. 1994. School Influences on Children's Development. Journal of Child Psychology and Psychiatry. 35(1):135-170.

Yamin, M. 2017. Metode Pembelajaran Bahasa Inggris di Tingkat Dasar. Pesona Dasar (Jurnal Pendidikan Dasar dan Humaniora). 1(5):82-97. 